\title{
PENGGUNAAN ABU SEKAM PADI DAN KAPUR SEBAGAI BAHAN PENGGANTI SEBAGIAN SEMEN KOMPOSIT PADA PEMBUATAN PAVING BLOCK
}

\author{
Prama Setiawan, Prihantono, dan Gina Bachtiar
}

\begin{abstract}
This research do for know function Rice Hulk Ash (RHA) and chalk in five do such as doing $A$ (without RHA and chalk) and doing $B, C, D$ dan $E$ with variation $2,5 \% ; 5 \% ; 7,5 \%$ dan $10 \%$ cement weight for paving block.

This research used experiment method follow SNI sand test and quality test doing in industrial department material research center DKI Jakarta. To make paving block doing in Harapan Jaya fabrique in M.Kahfi II Ciganjur, Jagakarsa. For composition a paving block is 1 cement : 6 sand.This research doing in April - July 2009.

Product of the research there is a different to point press test of the paving block in use a substitution RHA and chalk in the procentage $0 \% ; 2,5 \% ; 5 \%$; $7,5 \%$ dan $10 \%$.
\end{abstract}

Keyword: Rice Hulk Ash, cement weight, paving block

\section{PENDAHULUAN}

Seiring meningkatnya kebutuhan paving block mengakibatkan kebutuhan bahan baku paving block akan bertambah pula, yang pada akhirnya persediaan bahan baku semakin berkurang dan semakin mahal. Oleh karena itu perlu adanya upaya pemilihan bahan altermatif untuk kebutuhan bahan baku paving block untuk menekan biaya produksi. Salah satu bahan baku paving block adalah bahan pengikat seperti semen yang merupakan bahan dasar paling utama dalam pembuatannya.

Melalui penelitian pemanfaatan sumber daya alam, merupakan jalan terbaik untuk mendapatkan bahan alternative yang dibutuhkan. Salah satu dari pemanfaatan sumber daya alam tersebut adalah digunakannya kapur (lime) sebagai bahan alternative pada campuran paving block.

Sementara itu, Indonesia sebagai negara dengan hasil pertanian terbesarnya adalah padi karena makanan pokok masyarakat adalah nasi. Dan sekam adalah produk samping dari 
penggilingan padi, yaitu kulit luar dari padi. Abu sekam mengandung silica 65\% - 95\% sebagai komponen utama (Dardjo Somaatmadja, 1980).

\section{Pembatasan Masalah}

Pada penelitian ini, penulis membatasi permasalahan yang diteliti sebagai berikut:

1. Variabel yang diteliti adalah kuat tekan paving block mutu C SNI.

2. Kuat tekan paving block menggunakan abu sekam padi dan kapur sebagai pengganti sebagian semen komposit dengan presentase $0 \% ; 2,5 \% ; 5 \% ; 7,5 \%$ dan $10 \%$ dari berat semen komposit.

3. Komposisi campuran paving block 1 semen : 6 pasir untuk mutu kelas $\mathrm{C}$.

\section{Perumusan Masalah}

Dari pembatasan masalah yang diuraikan diatas maka dapat dirumuskan permasalahan sebagai berikut :

1. Apakah terdapat pengaruh penggunaan kapur dan abu sekam dengan presentasi $0 \% ; 2,5 \% ; 5 \% ; 7,5 \%$ dan $10 \%$ dari berat semen dalam campuran paving block terhadap standar kuat tekan paving block?

2. Apakah kuat tekan maksimum paving block yang menggunakan abu sekam padi dan kapur sebagai pengganti sebagian semen memenuhi syarat kuat tekan paving block mutu C SNI?

\section{Kegunaan Penelitian}

Hasil dari penelitian diharapkan dapat:

1. Memberi pengetahuan mengenai penggunaan abu sekam padi dan kapur sebagai alternatif bahan pada pembuatan paving block dengan harga yang lebih ekonomis namun tetap menghasilkan kuat tekan sesuai standar bata beton (paving block).

2. Memberikan sumbangan pemikiran bagi masyarakat mengenai manfaat abu sekam padi dan kapur sebagai bahan pengganti sebagian semen untuk 
pembuatan paving block, khususnya bagi masyarakat yang tinggal di wilayah yang banyak menghasilkan kapur dan wilayah pertanian. 


\section{Kerangka Teoritis}

\section{Bata Beton (Paving Block)}

Bata beton (paving block) adalah suatu komposisi bahan bangunan yang dibuat dari campuran semen Portland atau bahan perekat hidrolis sejenisnya, air dan agregat dengan atau tanpa bahan tambahan lainnya yang tidak mengurangi mutu bata beton itu (SNI-03-0691-1996, h.1).

Paving Block merupakan salah satu bahan bangunan yang biasa digunakan sebagai salah satu alternatif penutup tanah. Biasanya paving block digunakan di untuk trotoar, tempat parkir, jalan setapak pada taman dan jalan untuk perumahan. Paving block dikenal juga dengan sebutan bata beton (concrete block) atau cone block. Keuntungan bila menggunakan bata beton antara lain proses pemasangan yang relative mudah karena hanya diletakkan dan dipadatkan di atas tanah yang diberi lapisan pasir yang merata. Penggunaan bata beton juga baik untuk lingkungan karena air hujan dapat meresap ke dalam tanah melalui sela-sela antara bata beton, serta bata beton beraneka ukuran dan warna sehingga terlihat indah digunakan.

\section{a. Bahan Baku Bata Beton (Paving Block)}

Bahan baku pembuatan paving block pada umumnya terdiri dari semen, agrega dan air.

\section{1) Semen}

Tabel 1. Komposisi Kimia Semen Portland

\begin{tabular}{|l|l|}
\hline Komposisi Kimia & Kadar $(\%)$ \\
\hline Kapur $(\mathrm{CaO})$ & $58-65$ \\
Silika $\left(\mathrm{SiO}_{2}\right)$ & $20-26$ \\
Alumunium Oksida $\left(\mathrm{Al}_{2} \mathrm{O}_{3}\right)$ & $5-9$ \\
Oksida $\left(\mathrm{Fe}_{2} \mathrm{O}_{3}\right)$ & $1-5$ \\
Magnesia $(\mathrm{MgO})$ & $1-4$ \\
Trioksid Belerang $\left(\mathrm{SO}_{3}\right)$ & $0,5-2$ \\
Belerang (S) & $0,3-2$ \\
\hline
\end{tabular}

Sumber : SNI 15-2049-1995, Semen Portland

\section{2) Agregat Halus (Pasir)}

Syarat-syarat agregat halus tercantum pada SNI 03-1750-1990. 
3) Air

Air yang digunakan untuk pembuatan paving block harus bersih, tidak berwarna dan berbau (layak untuk minum).

\section{b. Syarat Mutu Bata Beton (Paving Block)}

Syarat mutu paving block tercantum pada SNI 03-0691-1996, yaitu terdiri :

1) Sifat Tampak

Bata beton harus mempunyai permukaan yang rata, tidak ada retak-retak dan cacat, bagian sudut dan rusuknya tidak mudah direpihkan dengan kekuatan jari tangan.

2) Ukuran

Bata beton harus mempunyai ukuran tebal minimum $60 \mathrm{~mm}(6 \mathrm{~cm})$ dengan toleransi $\pm 8 \%$. Panjang paving block $20 \mathrm{~cm}$ dan lebar $10 \mathrm{~cm}$.

3) Sifat Fisika

Bata beton harus mempunyai sifat-sifat fisika seperti pada berikut :

Tabel 2. Syarat Fisika Paving Block

\begin{tabular}{|r|r|r|r|r|c|}
\hline \multirow{2}{*}{ Mutu } & \multicolumn{2}{|c|}{$\begin{array}{c}\text { Kuat Tekan } \\
\text { (MPa) }\end{array}$} & \multicolumn{2}{c|}{$\begin{array}{c}\text { Ketahanan Aus } \\
\text { (mm/menit) }\end{array}$} & $\begin{array}{c}\text { Penyerapan } \\
\text { Air rata-rata maks. }\end{array}$ \\
\cline { 2 - 6 } & Rata-rata & Min. & Rata-rata & Min. & $(\%)$ \\
\hline A & 40 & 35 & 0,090 & 0,103 & 3 \\
B & 20 & 17,0 & 0,130 & 0,149 & 6 \\
C & 15 & 12,5 & 0,160 & 0,184 & 8 \\
D & 10 & 8,5 & 0,219 & 0,251 & 10 \\
\hline
\end{tabular}

Sumber : SNI 03-0691-1996, Bata Beton (Paving Block)

\section{c. Proses Pembuatan Bata Beton (Paving Block)}

Pada prinsipnya proses pembuatan paving block sama dengan proses pembuatan bata beton (batako), hanya saja berbeda pada perbandingan campuran, bentuk dan ukurannya. 
Pembuatan paving block pada penelitian ini dikerjakan menggunakan mesin pres. Yaitu dengan cara campuran semen, pasir dan air dimasukkan ke dalam cetakan pada mesin pres dan tuas ditekan sehingga proses pemadatannya lebih baik karena udara yang terjebak dalam campuran paving block akan keluar. Setelah proses pencetakkan selesai, paving block disiram dan diangin-anginkan kurang lebih empat minggu, kemudian paving block siap digunakan.

\section{d. Ketahanan Aus}

Yang dimaksud ketahanan aus adalah kemampuan suatu benda dalam menerima gesekan. Paving block biasa digunakan untuk penutup jalan baik untuk kendaraan atau untuk pejalan kaki, gesekan dengan ban atau alas kaki pejalan kaki berpengaruh sebagai penyebab keausan jalan. Jalan yang aus akan menjadi licin terutama bila kondisi basah karena hujan dan dapat menimbulkan kecelakaan bagi penggunanya.

\section{e. Penyerapan Air}

Penyerapan air perlukan untuk mengetahui mutu paving block, karena semakin tinggi mutunya semakin kecil daya serap airnya. Jika daya serap paving block tinggi akan menyebabkan paving block mudah hancur.

Daya serap air dirumuskan sebagai berikut :

$$
\text { Penyerapan Air }=\frac{\mathrm{A}-\mathrm{B}}{\mathrm{B}} \times 100 \%
$$

Keterangan :

$$
\begin{array}{ll}
\text { A } & =\text { Berat paving block kondisi basah } \\
B & =\text { Berat paving block kondisi kering }
\end{array}
$$

\section{f. Kuat tekan Paving Block}


Kuat tekan paving block pada dasarnya sama dengan kuat tekan beton, yaitu besarnya beban per satuan luas. Pengujianya dengan cara benda uji dibebani gaya tekan tertentu menggunakan mesin tekan.

\section{g. Uji Natrium Sulfat}

Menurut SNI 03-0691-1996 paving block harus diuji ketahanan sulfat karena pada nantinya paving block akan diletakkan di luar ruangan dan kontak langsung dengan tanah.

\section{Kapur}

Batu kapur banyak dimanfaatkan di sektor konstruksi, industri dan pertanian. Pada sektor konstruksi, batu kapur digunakan untuk bahan pondasi bangunan dan jalan raya serta untuk bahan bangunan. Batu kapur bila diolah akan menjadi kapur, dengan kapur adalah bahan dasar pembuatan semen.

Hampir dua pertiga bagian semen terbentuk dari zat kapur yang proporsinya berperan penting terhadap sifat-sifat semen ( L.J. Mudock dan K.M. Brook, 1999, h.65). Kapur dihasilkan oleh proses kimia dan mekanis di alam. Kapur sudah digunakan untuk sebagai bahan adukan dan plesteran sejak berabad-abad lalu (L.J. Mudock dan K.M. Brook, 1999,h.20). Kapur dihasilkan dari proses pembakaran batu kapur (lime stone) atau kalsium karbonat pada tungku tinggi yang berbentuk vertical atau tungku putar pada suhu $800^{0}-1200^{\circ} \mathrm{C}$. Batu kapur atau batu gamping adalah batuan sedimen yang terdapat di alam. Batu kapur banyak terdapat di gunung kapur yang tersebar di Indonesia mulai dari sumatera, jawa sampai pulau-pulau di bagian timur Indonesia (Murni A. dan Sudirman H, 2002, hal.194-199).

Tabel 3. Komposisi Kimia Kapur

\begin{tabular}{|l|l|l|}
\hline No & Unsur Kimia & Jumlah \\
\hline 1 & $\mathrm{CaO}$ & $50,84 \%$ \\
\hline 2 & $\mathrm{Na}_{2} \mathrm{O}$ & $0,095 \%$ \\
\hline 3 & $\mathrm{Fe}_{2} \mathrm{O}_{3}$ & $0,41 \%$ \\
\hline 4 & $\mathrm{MgO}$ & $2,72 \%$ \\
\hline 5 & $\mathrm{~K}_{2} \mathrm{O}$ & $0,32 \%$ \\
\hline
\end{tabular}




\begin{tabular}{|l|l|l|}
\hline 6 & $\mathrm{Al}_{2} \mathrm{O}_{3}$ & $0,682 \%$ \\
\hline 7 & $\mathrm{SiO}_{2}$ & $0,00 \%$ \\
\hline
\end{tabular}

Sumber: Sihotang, Abinhot dan Hazairin, 2002.

\section{Abu Sekam Padi}

Sekam padi sebagai limbah dari penggilingan gabah, saat ini dimanfaatkan masyarakat sebagai bahan bakar pembuatan genteng dan batu bata merah yang dilakukan secara konvensional dan abunya tidak dimanfaatkan. Hal ini sangat disayangkan karena abu sekam padi terbukti dapat dimanfaatkan dalam industri kimia, bahan bangunan, industri karet dll, karena abu sekam padi terdiri dari Opaline Silika yang terdapat di dalam jaringan selulosanya, sedangkan bahan anorganik yang terdapat dalam sisa pembakaran sekam padi adalah $65 \%$ - 95\% silica $\left(\mathrm{SiO}_{2}\right)$ sebagai komponen utama dan sekitar 10\% $15 \%$ adalah karbon $(\mathrm{C}){ }^{1}$

Unsur di dalam sekam padi, seperti air akan menguap pada suhu di atas $100^{\circ} \mathrm{C}$ dan pada suhu di atas $300^{\circ} \mathrm{C}$ selulosa akan berubah menjadi arang/karbon, pembakaran pada suhu lebih tinggi di atas $400^{\circ} \mathrm{C}$, sekam padi akan menghasilkan silika dalam dua bentuk yaitu amorf dan kristal . ${ }^{2}$ Abu sekam padi yang dihasilkan dari pembakaran sekam pada temperatur $500^{\circ} \mathrm{C}$ dengan lama 105 menit atau lebih akan memberikan kandungan silika amorf optimum sedikitnya $86 \%$. Pembuatan abu sekam padi oleh petani padi memberikan kadar silika berkisar $70 \%$.

Tabel 4. Susunan Kimia Sekam Padi

\begin{tabular}{|l|l|l|l|l|}
\hline No & Unsur Organik & Kadar & Unsur Anorganik & Kadar \\
\hline 1 & Protein Kasar & $1,5-7 \%$ & $\mathrm{SiO}_{2}$ & $82-87,6 \%$ \\
\hline 2 & Serat Kasar & $31,5-50 \%$ & $\mathrm{CaO}$ & $0,84-2 \%$ \\
\hline 3 & Extrak tanpa Nitrogen & $24,5-38,8 \%$ & $\mathrm{MgO}$ & $0,81-2 \%$ \\
\hline
\end{tabular}

${ }^{1}$ Dardjo Somaatmadja, Aspek-aspek Kimia yang Terkandung dalam Abu Sekam Padi, 1980.

2 Priyosulistyo dkk, Pemanfaatan Limbah Abu Sekam Padi untuk Peningkatan Mutu Beton, 1999. 


\begin{tabular}{|l|l|l|l|l|}
\hline 4 & Selulosa & $16-22 \%$ & $\mathrm{~K}_{2} \mathrm{O}$ & $0,19-22,8 \%$ \\
\hline 5 & Lignin & $20-27,5 \%$ & $\mathrm{Na}_{2} \mathrm{O}$ & $2-22,8 \%$ \\
\hline 6 & Pentosa & $31,5-50 \%$ & $\mathrm{P}_{2} \mathrm{O}_{3}$ & $0,2-3 \%$ \\
\hline 7 & Lemak Kasar & $0,5-3 \%$ & $\mathrm{SO}_{3}$ & $0,10-0,15 \%$ \\
\hline
\end{tabular}

Sumber : Dudung Kusmara, Pemanfaatan Limbah Abu Sekam Padi Pada Pembuatan

Genteng Beton (Jakarta: Jurnal Penelitian Pemukiman vol. IV, 1990)

\section{Kerangka Berpikir}

Berdasarkan deskripsi teori di atas, paving block dibuat dengan bahan semen Portland komposit sebagai bahan pengikat, agregat halus sebagai bahan pengisi dan air dengan komposisi tertentu. Berdasarkan tabel 1, kandungan semen porland memiliki kandungan kapur $58-65 \%$ dan silika $20-26 \%$. Kapur dan silika adalah merupakan komponen utama penyusun semen.

\section{Perumusan Hipotesis}

1. Terdapat pengaruh penggunaan kapur dan abu sekam padi sebagai pengganti sebagian semen komnposit dengan presentase $0 \% ; 2,5 \% ; 5 \% ; 7,5 \%$ dan $10 \%$ dari berat semen komposit dengan komposisi campuran 1 semen : 6 pasir untuk mencapai paving block dengan mutu kelas $\mathrm{C}(15 \mathrm{MPa})$.

2. Kuat tekan paving block maksimum pada salah satu presentase penggunaan kapur dan abu sekam padi sebagai pengganti sebagian semen, mampu mencapai kuat tekan paving block dengan mutu kelas $\mathrm{C}(15 \mathrm{MPa})$.

\section{METODOLOGI PENELITIAN}

\section{A. Tujuan Penelitian}

1. Mengetahui pengaruh penggunaan abu sekam padi dan kapur sebagai bahan pengganti sebagian semen komposit dengan persentase $0 \% ; 2,5 \% ; 5 \% ; 7,5 \%$ dan $10 \%$ dari berat semen komposit terhadap kuat tekan bata beton (paving block) dengan standart SNI kelas mutu C (15 MPa) dengan komposisi campuran 1 semen komposit : 6 pasir.

2. Mengetahui apakah kuat tekan paving block maksimum pada salah satu presentase penggunaan abu sekam padi dan kapur sebagai bahan pengganti 
sebagian semen komposit, mampu mencapai kuat tekan paving block dengan kelas mutu C sesuai SNI.

\section{B. Tempat dan Waktu Penelitian}

Penelitian ini dilaksanakan di Balai Penelitian Bahan Dinas Perindustrian DKI Jakarta, yang terletak di jalan Jendral Suprapto Cempaka Putih, Jakarta Pusat. Pembuatan paving block dilakukan di Pabrik Harapan Jaya di Jln. M. Kahfi II Warung Silah ,Ciganjur Jagakarsa, Jakarta Selatan. Penelitian ini dilaksanakan pada bulan April - Juli 2009

\section{Variabel Penelitian}

Variabel pada penelitian ini adalah :

1. Variabel bebas adalah bata beton (paving block) dengan menggunakan bahan subtitusi abu sekam padi dan kapur sebagai bahan pengganti sebagian semen komposit dengan persentase $0 \% ; 2,5 \% ; 5 \% ; 7,5 \%$ dan $10 \%$.

2. Variabel terikat adalah kuat tekan bata beton (paving block) mutu C SNI (15MPa).

\section{Metode Penelitian}

Metode penelitian yang digunakan dalam penelitian ini adalah metode eksperimen di laboratorium dengan benda uji paving block yang menggunakan abu sekam padi dan kapur sebagai bahan pengganti semen komposit dengan persentase $0 \% ; 2,5 \% ; 5 \%$; $7,5 \%$ dan $10 \%$ dari berat semen terhadap nilai kuat tekan paving block berdasarkan SNI mutu C dengan campuran 1 semen komposit : 6 pasir.

\section{PEMBAHASAN dan HASIL PENELITIAN}

\section{A. Hasil Pengukuran Paving Block}

Tabel 5. Ukuran Paving Block

\begin{tabular}{|c|c|c|c|c|}
\hline \multirow{3}{*}{ Perlakuan } & \multicolumn{4}{|c|}{ Ukuran Rata-Rata Paving Block } \\
\cline { 2 - 5 } & Berat & Panjang & Lebar & Tebal \\
& (gram) & $(\mathrm{cm})$ & (cm) & (cm) \\
\hline
\end{tabular}




\begin{tabular}{|c|c|c|c|c|}
\hline A & 2.990 & 20,21 & 10,67 & 6,74 \\
\hline$B$ & 2.860 & 20,24 & 10,63 & 6,64 \\
\hline C & 2.795 & 20,24 & 10,60 & 6,67 \\
\hline D & 2.710 & 20,22 & 10,59 & 6,69 \\
\hline E & 2.680 & 20,22 & 10,62 & 6,59 \\
\hline
\end{tabular}

Dari tabel di atas, dapat dilihat bahwa dengan menggunakan abu sekam padi dan kapur sebagai pengganti sebagian semen menghasilkan paving block yang lebih ringan. Hal ini menunjukkan adanya pengaruh penggunaan abu sekam padi dan kapur pada pembuatan paving block. 
B. Hasil Pengujian Penyerapan Air

Tabel 6. Pengujian Penyerapan Air

\begin{tabular}{|c|c|c|}
\hline Perlakuan & $\begin{array}{l}\text { Penyerapan Air Rata-Rata } \\
\text { (\%) }\end{array}$ & Jumlah Sampel \\
\hline A & 7,244 & 5 \\
\hline B & 7,288 & 5 \\
\hline C & 7,348 & 5 \\
\hline D & 7,390 & 5 \\
\hline E & 7,470 & 5 \\
\hline
\end{tabular}

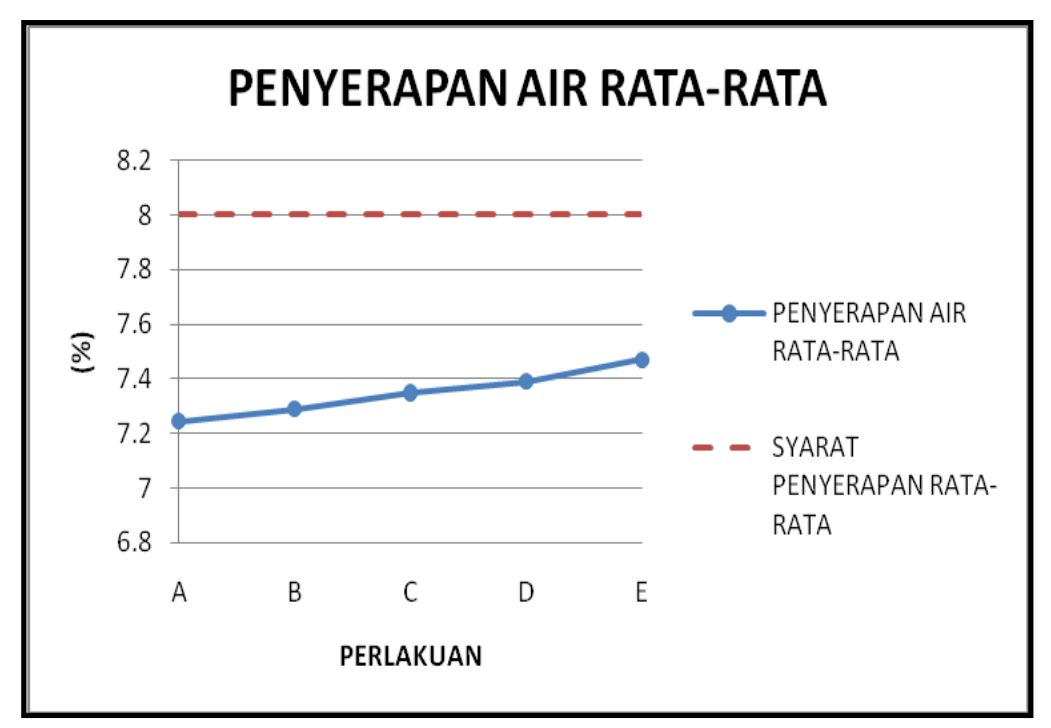

Gambar 1.Grafik Penyerapan Air Rata-Rata

Berdasarkan Tabel 6 dan Gambar 1 di atas, terlihat ada kecenderungan peningkatan nilai penyerapan air pada paving block, dengan bertambahnya presentase abu sekam padi dan kapur sehingga penyerapan air makin besar. Menurut SNI 03-0691-1996, penyerapan air paving block untuk mutu C, tidak boleh melebihi $8 \%$. Dari tabel di atas dapat disimpulkan bahwa penyerapan air pada paving block 
dengan menggunakan abu sekam padi dan kapur sebagai bahan pengganti sebagian semen komposit dapat memenuhi standar paving block kelas mutu $\mathrm{C}$.

C. Hasil Pengujian Ketahanan Aus

Tabel 7. Pengujian Ketahanan Aus

\begin{tabular}{|c|c|c|}
\hline Perlakuan & $\begin{array}{c}\text { Ketahanan Aus Rata-Rata } \\
\text { (mm/menit) }\end{array}$ & $\begin{array}{c}\text { Jumlah } \\
\text { Sampel }\end{array}$ \\
\hline A & 0,152 & 5 \\
\hline B & 0,155 & 5 \\
\hline C & 0,158 & 5 \\
\hline D & 0,162 & 5 \\
\hline E & 0,168 & 5 \\
\hline
\end{tabular}

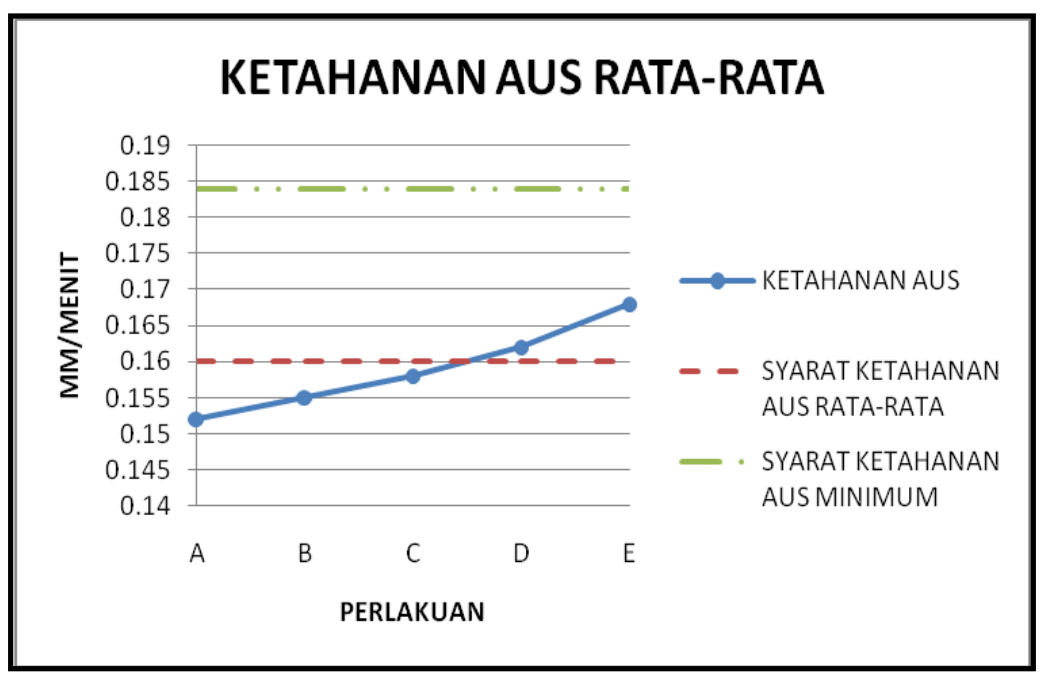

Gambar 2.Grafik Ketahanan Aus Rata-Rata

Dari tabel dan grafik di atas, nilai rata-rata ketahanan aus kelompok $A, B$ dan $\mathrm{C}$ memenuhi syarat mutu ketahanan aus paving block mutu $\mathrm{C}$ dengan nilai rata-rata ketahanan aus sebesar $0,160 \mathrm{~mm} /$ menit. Kelompok $D$ dan $E$ termasuk dalam mutu $D$ yaitu dengan nilai rata-rata ketahanan aus sebesar $0,219 \mathrm{~mm} / \mathrm{menit}$. 
D. Hasil Pengujian Natrium Sulfat

Tabel 8. Pengujian Natrium Sulfat

\begin{tabular}{|c|c|c|}
\hline Perlakuan & $\begin{array}{c}\text { Ketahanan Natrium Sulfat } \\
(\%)\end{array}$ & $\begin{array}{c}\text { Jumlah } \\
\text { Sampel }\end{array}$ \\
\hline A & 0,655 & 2 \\
\hline B & 0,725 & 2 \\
\hline C & 0,765 & 2 \\
\hline D & 0,845 & 2 \\
\hline E & 0,885 & 2 \\
\hline
\end{tabular}

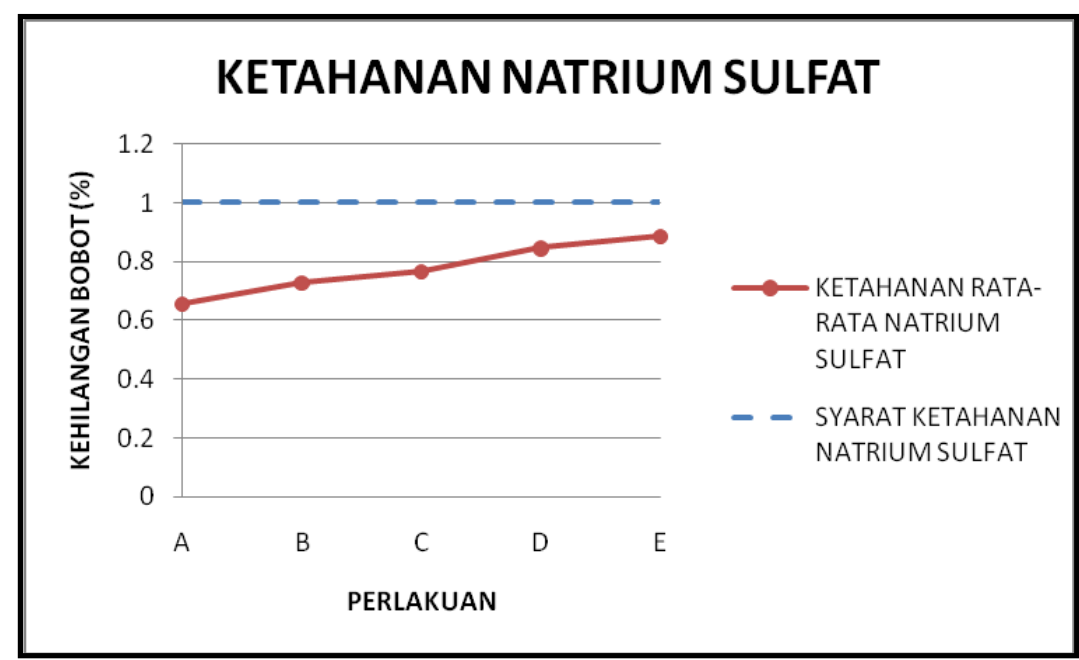

Gambar3. Grafik Ketahanan Natrium Sulfat

Berdasarkan tabel dan garfik di atas, nilai rata-rata ketahanan terhadap natirum sulfat untuk perlakuan A, B, C, D dan E memenuhi syarat SNI 03-0691-1996 yaitu kurang dari $1 \%$. 
E. Hasil Pengujian Kuat Tekan Paving Block

Tabel 9. Pengujian Penyerapan Air

\begin{tabular}{|c|c|c|}
\hline \multirow{2}{*}{ Perlakuan } & \multicolumn{2}{|c|}{ Nilai Kuat Tekan Rata-Rata } \\
\cline { 2 - 3 } & $\mathrm{Kg} / \mathrm{cm}^{2}$ & MPa \\
\hline A & 154.219 & 15.726 \\
\hline B & 153.641 & 15.667 \\
\hline C & 152.219 & 15.522 \\
\hline D & 149.109 & 15.205 \\
\hline E & 146.48 & 14.903 \\
\hline
\end{tabular}

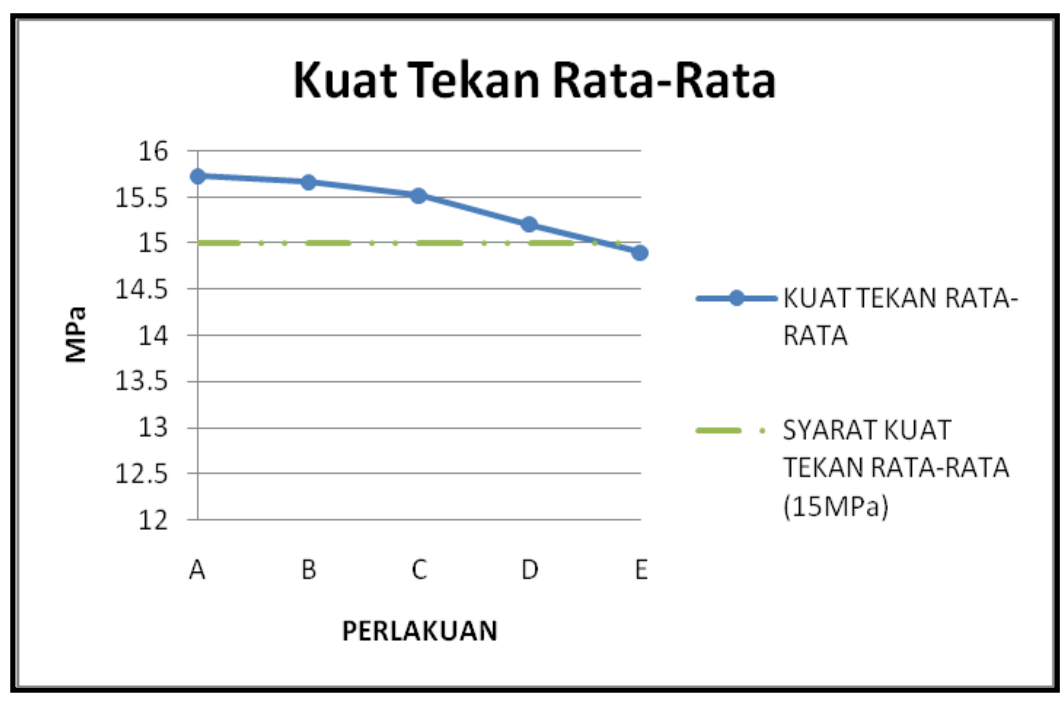

Gambar 4.Grafik Kuat Tekan Rata-Rata

Berdasarkan tabel dan grafik di atas dapat dilihat bahwa kuat tekan paving block yang tidak menggunakan abu sekam padi dan kapur menghasilkan kuat tekan 15,726 MPa dan paving block yang menggunakan abu sekam padi dan kapur sebesar 2,5\%;5\%;7,5\% dan 10\% berturut-turut adalah sebesar 15,667 MPa, 15,522 MPa, 15,205 MPa dan 14,903 MPa. 


\section{KESIMPULAN}

\section{A. Kesimpulan}

Berdasarkan hasil penelitian terhadap paving block dengan menggunakan abu sekam padi dan kapur sebagai bahan pengganti sebagian semen komposit, maka dapat disimpulkan sebagai berikut:

1. Terdapat pengaruh penggunaan abu sekam padi dan kapur sebagai pengganti sebagian semen komposit dengan presentase $0 \% ; 2,5 \% ; 5 \% ; 7,5 \%$ dan $10 \%$ dari berat semen komposit dengan komposisi 1 semen komposit : 6 pasir untuk mencapai paving block mutu C. Nilai kuat tekan rata-rata paving block A (kontrol) sebesar $15,726 \mathrm{MPa}$, paving block yang menggunakan abu sekam padi dan kapur $2,5 \% ; 5 \% ; 7,5 \%$ dan $10 \%$ berturut-turut sebesar 15,667 MPa, 15,522 MPa, 15,205 MPa dan 14,903 MPa sehingga kelompok A (kontrol), B (2,5\%), C (5\%) dan D $(7,5 \%)$ memenuhi standar mutu C sedangkan kelompok $E(10 \%)$ memenuhi standar mutu D.

2. Nilai kuat tekan rata-rata paving block yang menggunakan abu sekam padi dan kapur sebagai pengganti sebagian semen komposit untuk presentase $0 \% ; 2,5 \%$; $5 \%$ dan $7,5 \%$ termasuk kedalam mutu $C$ dan untuk presentase $10 \%$ masuk kedalam mutu $D$.

\section{Implikasi}

1. Dari hasil penelitian yang telah dilakukan, terbukti bahwa penggunaan abu sekam padi dan kapur dengan presentase $0 \% ; 2,5 \% ; 5 \% ; 7,5 \%$ dan $10 \%$ menurunkan mutu paving block. Hanya sampai presentase $7,5 \%$ yang masih dapat menghasilkan nilai kuat tekan mutu C sedangkan untuk presentase 10\% masuk kedalam mutu D.

2. Hasil dari penelitian ini, maka implikasi / tindak lanjut hasil penelitian adalah memberi informasi kepada kita semua bahwa digunakannya abu sekam padi dan kapur sebagai pengganti sebagian semen pada pembuatan paving block dapat menurunkan mutu. Sehingga tujuan ekonomis tidak tercapai, karena tujuan ekonomis dapat tercapai jika penggunaan abu sekam padi dan kapur sebagai 
bahan pengganti sebagian semen tidak menurunkan mutu dari paving block itu sendiri.

\section{Saran}

Untuk penelitian lebih lanjut, disarankan:

1. Untuk melanjutkan penelitian dengan abu sekam padi dan kapur digunakan sebagai bahan tambah pada pembuatan paving block.

2. Melakukan pengujian terhadap seluruh bahan yang akan digunakan pada pembuatan paving block termasuk dengan semen yang digunakan

\section{DAFTAR PUSTAKA}

Dardjo Somaatmadja, Aspek-aspek Kimia yang terkandung dalam abu sekam padi, 1980.

L.J. Mudock dan K.M. Brook, Bahan dan Praktek Beton (Jakarta : Erlangga, 1999), h.65.

Murni A. dan Sudirman H. Pemanfaatan Potensi Batu Kapur di Kawasan Timur Indonesia, (Jurnal Teknik Sipil no.3, 2002), hal.194-199

Sihotang, Abinhot dan Hazairin, 2002

SNI-03-0691-1996, Bata Beton (paving block), (Jakarta : BSN, 1996) h.1. 